\title{
FAKTOR-FAKTOR YANG BERHUBUNGAN DENGAN LASERASI PERINEUM PADA KEHAMILAN NORMAL DI RSUD DR. IBNU SOETOWO BATURAJA KABUPATEN OGAN KOMERING ULU
}

\author{
Sabtian Sarwoko \\ Program Studi Kesehatan Masyarakat STIKES AI-Ma'Arif Baturaja \\ Email: sabtian.sarwoko@gmail.com
}

\begin{abstract}
ABSTRAK
Pendahuluan: Banyak kemungkinan masalah yang muncul pada ibu pasca persalinan salah satunya adalah laserasi perineum. Laserasi perineum dapat menjadi suatu hal yang mengancam jika diikuti dengan perdarahan. Ada beberapa factor yang dapat mengakibatkan laserasi perineum yaitu jarak kehamilan,, berat bayi lahir, dan usia ibu. Tujuan penelitian: ini ditujukan untuk mengetahui factor apa saja yang berhubungan dengan laserasi perineum pada kehamilan normal. Di RS Ibnu Sotowo Baturaja. Metode Penelitian: ini menggunakan survey analitik dengan pendekatan cross sectional. Populasi penelitian ini adalah seluruh ibu bersalin normal di RSUD dr. Ibnu Soetowo Baturaja Kabupaten Ogan Komering Ulu, dengan sampel pengambilan sampel secara random sampling dengan jumlah sampel 177 responden. yang selanjutnya dilakukan uji statistik Chi-Square, dengan derajat kepercayaan 95\%. Hasil penelitian: menunjukkan bahwa ada hubungan jarak persalinan dengan kejadian laserasi perineum ( $p$ value 0,002), ada hubungan berat badan lahir dengan kejadian laserasi perineum ( $p$ value 0,001$)$ serta ada hubungan umur ibu dengan kejadian laserasi perineum ( $p$ value 0,001$)$.
\end{abstract}

Kata Kunci: kejadian laserasi perineum, jarak persalinan, berat badan lahir, umur ibu.

\section{ABSTRACT}

Bacground: Many possible problems that arise in mothers after childbirth one of which is perineal laceration. Perineal laceration can be a threat if followed by bleeding. There are several factors that can cause perineal laceration, namely the distance of pregnancy, birth weight, and maternal age. This study aimed to determine what factors are associated with perineal laceration in normal pregnancy. At the Ibnu Sotowo Baturaja Hospital. Methode This research uses analytic survey with cross sectional approach. The study population was all normal delivery mothers at RSUD dr. Ibnu Soetowo Baturaja Ogan Komering Ulu Regency, with a random sampling with 177 respondents. the Chi-Square statistical test was then performed, with a 95\% confidence level. The results showed that there was a relationship between the distance of labor with the incidence of perineal laceration ( $p$ value 0.002), there was a relationship of birth weight with the incidence of perineal laceration ( $p$ value 0.001 ) and there was a relationship between maternal age and the incidence of perineal laceration ( $p$ value 0.001).

Keywords: perineal laceration event, labor spacing, birth weight and maternal age.

\section{PENDAHULUAN}

Berdasarkan Survei Demografi serta Kesehatan Indonesia (SDKI) tahun 2012, rata-rata $\mathrm{AKI}$ tercatat mencapai 359 per
100 ribu kelahiran hidup. Ini menempatkan Indonesia sebagai salah satu negara dengan AKI tertinggi asia serta tertinggi ke-3 di kawasan ASEAN. Angka itu lebih 
dari sepuluh kali AKI dibandingkan dengan negara di Malaysia serta Sri Lanka. Tingginya AKI di Indonesia saat ini, tidak tercapainya program Millenium Development Goals (MDGs) tahun 2015 dengan harapan menurunkan AKI sebesar 102/100.000 kelahiran hidup. Sebagai tindak lanjut MDGs pemerintah melakukan tranformasi Sustainable Development Goals (SDGs) untuk menurunkan AKI sebesar 70/100.000 kelahiran hidupa pada tahun 2030 (Rosmawar, 2015).

Mortalitas serta morbilitas pada wanita hamil serta bersalin adalah masalah besar di negara berkembang. Diperkirakan setiap tahunnya 300.000 ibu di dunia meninggal ketika melahirkan. Sebanyak 99 persen kasus kematian ibu terjadi di negara berkembang. Hal ini terungkap berdasarkan laporan terbaru yang dirilis United Nations Population fund (UNFPA). Sampel dari studi ini dilakukan di 58 Negara di dunia, termasuk Indonesia (Fajrin serta Fitriani, 2015).

Perdarahan pasca kehamilan dapat menyebabkan kematian ibu $45 \%$ terjadi pada 24 jam pertama setelah bayi lahir, $68-73 \%$ dalam satu minggu setelah bayi lahir, serta $82-88 \%$ dalam 2 minggu setelah bayi baru lahir. Yang terjadi pada 24 jam pertama setelah bayi lahir disebabkan oleh atonia uteri, berbagai robekan jalan lahir, serta sisanya adalah sisa plasenta. laserasi perineum dapat menyebabkan robekan jalan lahir serta dapat menyebabkan perdarahan (Rahayu, 2016).

Laserasi perineum merupakan penyebab perdarahan kedua setelah atonia uteri, hal ini sering terjadi pada primigravida karena pada primigravida perineum masih utuh. Pada jarak kehamilan kurang dari 2 tahun yang mengalami robekan perineum dikarenakan pemulihan kehamilan sebelumnya belum sempurna serta robekan perineum dapat terjadi. Sesertagkan pada umur ibu beresiko rantang terhadap kelainan kehamilan/faktor resiko tinggi kehamilan. Faktor yang mempengaruhi laserasi perineum yaitu faktor maternal, faktor janin serta faktor penolong (Sabri. dkk. 2016).

Angka kejadian laserasi di seluruh dunia terjadi 2,7 juta kasus robekan (ruptur) perineum pada ibu bersalin. Angka ini diperkirakan mencapai 6,3 juta pada tahun 2020. Di Amerika dari 26 juta ibu bersalin, terdapat $40 \%$ mengalami laserasi perineum. Di Asia masalah laserasi perineum cukup banyak dalam masyarakat, $50 \%$ dari kejadian robekan perineum di dunia terjadi di Asia (Ristiati, dkk. 2016).

Hasil studi dari Pusat Penelitian serta Pengembangan (Puslitbang), yang melakukan penelitian pada beberapa Propinsi di Indonesia didapatkan bahwa satu dari lima ibu bersalin yang mengalami laserasi perineum akan meninggal dunia dengan persentase 21,74\% (Ristiati, dkk. 2016).

Cakupan pertolongan kehamilan oleh tenaga kesehatan di Provinsi Sumatera Selatan meningkat dari $79,25 \%$ pada tahun 2012 menjadi 134.759 (90,92\%) dari 148.223 ibu bersalin pada tahun 2015 . Cakupan kehamilan oleh tenaga kesehatan secara normal sebesar 102.432 $(76,01 \%)$ dengan kasus rupture perineum sebesar 32.327 (23,99\%) (Dinkes Sumsel, 2015).

Berdasarkan penelitian Prawita (2015) DI RSUD Langsa kota Langsa Provinsi Aceh. Didapatkan hasil ada hubungan antara jarak kehamilan dengan kejadian laserasi perineum dengan $p$-value 0,001

Menurut penelitian Rahmawati (2011) di RSIA Kumala Siwi Pencangan Jepara 
Didapatkan hasil ada hubungan antara berat badan lahir dengan kejadian laserasi perineum dengan $p$-value 0,016

Menurut penelitian Andriani (2018) di Di Puskesmas Tegalrejo Yogyakarta Didapatkan hasil ada hubungan antara umur ibu dengan kejadian laserasi perineum dengan $p$-value 0,008

Dari data yang diperoleh dari RSUD dr. Ibnu Soetowo angka kejadian laserasi perineum pada tahun 2015 di dapat sebesar 725 (40,14\%).kasus dari 1.806 ibu bersalin serta tahun 2016 di dapat sebesar 530 (31,9\%) kasus dari 1.661 .ibu bersalin serta tahun 2017 dari bulan januari-Maret di dapat kasus 62 (19,68\%) dari 315 ibu bersalin normal.

Berdasarkan latar belakang diatas peneliti menjadi tertarik untuk melakukan penelitian dengan judul faktor-faktor yang mempengaruhi terjadinya laserasi perineum pada kehamilan normal di RSUD dr. Ibnu Soetowo Baturaja Kabupaten Ogan Komering Ulu.

\section{METODE PENELITIAN}

Penelitian ini menggunakan survey analitik dengan pendekatan cross sectional. Populasi penelitian ini adalah seluruh ibu bersalin normal di RSUD dr. Ibnu Soetowo Baturaja Kabupaten Ogan Komering ULU, dengan sampel pengambilan sampel secara random sampling dengan jumlah sampel 177 responden. Analisa data menggunakan analisa univariat serta analisa bivariat dengan menggunakan tabel distribusi serta uji statistik Chi-Square, dengan derajat kepercayaan 95\%.

\section{HASIL}

Analisa ini dilakukan untuk mengetahui hubungan antara variabel independen (jarak kehamilan, BBL, serta umur ibu) dengan variabel dependen (kejadian laserasi periminum). Uji statistik yang digunakan adalah uji chi-square dengan batas kemaknaan $p$ value $\leq 0,05$ artinya ada hubungan yang bermakna (signifikan)

Tabel. 1

Hubungan Jarak Pesalinan dengan Kejadian Laserasi Perineum pada Kehamilan Normal di RSUD Dr. Ibnu Soetowo Baturaja Kabupaten Ogan Komering Ulu Tahun 2017

\begin{tabular}{|c|c|c|c|c|c|c|c|c|}
\hline \multirow{3}{*}{ No } & \multirow{3}{*}{ Jarak Persalinan } & \multicolumn{4}{|c|}{ Laserasi Periminum } & \multirow{2}{*}{\multicolumn{2}{|c|}{ Jumlah }} & \multirow{3}{*}{$p$ value } \\
\hline & & \multicolumn{2}{|c|}{$\mathrm{Ya}$} & \multicolumn{2}{|c|}{ Tidak } & & & \\
\hline & & $f$ & $\%$ & $f$ & $\%$ & $\Sigma$ & $\%$ & \\
\hline 1 & Beresiko & 26 & 59,1 & 18 & 40,9 & 44 & 100 & \multirow{3}{*}{0,002} \\
\hline \multirow[t]{2}{*}{2} & Tidak Beresiko & 9 & 6,8 & 124 & 93,2 & 133 & 100 & \\
\hline & Jumlah & 35 & 19,8 & 142 & 80,2 & 177 & 100 & \\
\hline
\end{tabular}

Dari tabel.1 diketahui bahwa jauh kehamilan beresiko yang mengalami laserasi periminum sebesar 26 responden $(59,1 \%)$, lebih besar dibanding dengan jarak kehamilan tidak beresiko yang mengalami laserasi periminum sebesar 9 responden $(6,8 \%)$.
Hasil uji statistik Chi-Square menunjukkan bahwa ada hubungan yang bermakna hantaran jarak persalinan dengan kejadian laserasi periminum dengan $p$ value 0,002 , 
Tabel. 2

Hubungan Berat Badan Lahir (BBL) dengan Kejadian Laserasi Perineum pada Kehamilan Normal di RSUD Dr. Ibnu Soetowo Baturaja Kabupaten Ogan Komering Ulu Tahun 2017

\begin{tabular}{|c|c|c|c|c|c|c|c|c|}
\hline \multirow{3}{*}{ No } & \multirow{3}{*}{ BBL } & \multicolumn{4}{|c|}{ Ruptur Periminum } & \multirow{3}{*}{$\Sigma$} & \multirow{3}{*}{$\%$} & \multirow{3}{*}{$p$ value } \\
\hline & & \multicolumn{2}{|c|}{ Ya } & \multicolumn{2}{|c|}{ Tidak } & & & \\
\hline & & $f$ & $\%$ & $f$ & $\%$ & & & \\
\hline 1 & Beresiko & 23 & 85,2 & 4 & 4,8 & 27 & 100 & \\
\hline 2 & Tidak Beresiko & 12 & 8,0 & 138 & 92,0 & 150 & 100 & 0,001 \\
\hline & Jumlah & 35 & 19,8 & 142 & 80,2 & 177 & 100 & \\
\hline
\end{tabular}

Dari tabel. 2 diketahui bahwa BBL beresiko yang mengalami laserasi periminum sebesar 23 responden $(85,2 \%)$, lebih besar dibanding dengan BBL tidak beresiko yang mengalami laserasi periminum sebesar 12 responden $(8,0 \%)$.
Hasil uji statistik Chi-Square menunjukkan bahwa ada hubungan yang bermakna hantaran berat baserta lahir (BBL) dengan kejadian laserasi periminum dengan $p$ value 0,001 , hal ini berarti hipotesa diterima.

Tabel. 3

Hubungan Umur lbu dengan Kejadian Laserasi Perineum pada Kehamilan Normal di RSUD Dr. Ibnu Soetowo Baturaja Kabupaten Ogan Komering Ulu

Tahun 2017

\begin{tabular}{|c|c|c|c|c|c|c|c|c|}
\hline \multirow{3}{*}{ No } & \multirow{3}{*}{ Umur lbu } & \multicolumn{4}{|c|}{ Ruptur Periminum } & \multirow{3}{*}{$\Sigma$} & \multirow{3}{*}{$\%$} & \multirow{3}{*}{$p$ value } \\
\hline & & \multicolumn{2}{|c|}{$\mathrm{Ya}$} & \multicolumn{2}{|c|}{ Tidak } & & & \\
\hline & & $f$ & $\%$ & $f$ & $\%$ & & & \\
\hline 1. & Beresiko & 27 & 46,6 & 31 & 53,4 & 58 & 100 & \\
\hline 2. & Tidak Beresiko & 8 & 6,7 & 111 & 93,3 & 119 & 100 & 0,001 \\
\hline & Jumlah & 35 & 19,8 & 142 & 80,2 & 177 & 100 & \\
\hline
\end{tabular}

Dari tabel. 2 diketahui bahwa umur ibu beresiko yang mengalami laserasi periminum sebesar 27 responden $(46,6 \%)$, lebih besar dibanding dengan umur ibu tidak beresiko yang mengalami laserasi periminum sebesar 8 responden $(6,7 \%)$. Hasil uji statistik Chi-Square menunjukkan bahwa ada hubungan yang bermakna hantaran umur ibu dengan kejadian laserasi periminum dengan $p$ value 0,001 , hal ini berarti hipotesa diterima.

\section{PEMBAHASAN}

Hasil analisa ada hubungan jarak kehamilan beresiko yang mengalami laserasi perineum sebesar 26 responden $(59,1 \%)$, lebih besar dibanding dengan jarak kehamilan tidak beresiko yang mengalami laserasi perineum sebesar 9 responden $(6,8 \%)$. Hasil uji statistik ChiSquare menunjukkan bahwa ada hubungan yang bermakna antara jarak kehamilan dengan kejadian laserasi perineum dengan $p$ value 0,002 .

Jarak kehamilan kurang dari dua tahun tergolong resiko tinggi karena dapat 
menimbulkan komplit pada kehamilan. jarak kelahiran $\geq 2$ tahun merupakan jarak kelahiran yang lebih aman bagi ibu serta janin. Begitu juga dengan keadaan jalan lahir yang mungkin pada kehamilan terdahulu mengalami robekan perineum pada derajat tiga atau empat, sehingga pemulihan belum sempurna serta robekan perineum dapat terjadi (Rosdiana, 2014).

Penelitian ini sejalan dengan penelitian yang dilakukan oleh Susanti, (2014) yang menyatakan bahwa jarak kehamilan ada hubunganya dengan kejadian laserasi perineum. Jarak kehamilan ibu sebagian besar berada pada kelompok jarak kehamilan yang berisiko. Hasil analisis distribusi berdasar jarak kehamilan ibu sebanyak 377 (94\%) serta jarak kehamilan tidak beresiko adalah 24 (6\%), ibu dengan jauh melahirkan beresiko yang mengalami laserasi perineum sebanyak $345(91,5 \%)$ sedangkan ibu dengan jarak kehamilan tidak beresiko yang mengalami laserasi perineum sebanyak 24 (34\%). Dari hasil analisis multivariat variabel jenis kehamilan ibu dengan laserasi perineum didapatkan $p$-value 0,008 artinya ada hubungan hantaran jauh kehamilan dengan laserasi perineum.

Dari penelitian diatas dapat ditarik asumsi bahwa jarak kehamilan mempengaruhi kejadian laserasi perineum. Makin pendek jarak kehamilan makin besar resiko terjadinya laserasi perineum. Hal ini disebabkan luka pada saat melahirkan sebelumnya, serta melahirkan dengan jauh kurang dari 2 tahun merupakan resiko tinggi bagi ibu. Sesertagkan pada jarak kehamilan yang tidak beresiko terjadi laserasi perineum, dikarenakan ibu kurang mengetahui bagaimana cara melahirkan yang benar seperti meneran sebelum waktunya atau belum ada kontraksi (his) serta juga karena bimbingan kehamilan yang salah sehingga dapat terjadi laserasi perineum.

Hasil analisa hubungan berat baserta lahir (BBL) mempengaruhi kejadian laserasi perineum, BBL beresiko yang mengalami laserasi perineum sebesar 23 responden $(85,2 \%)$, lebih besar dibanding dengan BBL tidak beresiko yang mengalami laserasi perineum sebesar 12 responden (8,0\%). Hasil uji statistik ChiSquare menunjukkan bahwa ada hubungan yang bermakna hantaran berat baserta lahir (BBL) dengan kejadian laserasi perineum dengan $p$ value 0,001 .

Berat baserta lahir adalah berat bayi lahir pada saat setelah dilahirkan. Berat baserta janin dapat mengakibatkan terjadinya rupture perineum yaitu berat baserta janin lebih dari 3500 gram, karena resiko trauma partus melalui vagina seperti distosia bahu serta kerusakan jaringan lunak pada ibu. Perkiraaan berat janin bergantung pada pemeriksaan klinik atau ultrasonografi. Pada masa kehamilan hendaknya terlebih dahulu mengukur tafsiran berat baserta janin (Hutomo, 2014).

Penelitian ini sejalan dengan penelitian yang dilakukan oleh Rosmawar (2016) dari 23 responden dengan Beresiko (berat baserta bayi besar) terdapat 22 orang $(95,7 \%)$ yang pernah mengalami laserasi serta dari 9 responden dengan Tidak Beresiko berat baserta bayi $<3500 \mathrm{gr}$ terdapat 8 orang $(6,8 \%)$ yang tidak pernah mengalami laserasi serta dari 5 responden. Secara statistik tingkat laserasi perineum dengan berat baserta bayi besar sangat bermakna (signifikan) dengan nilai $p$ value 0,000 ( $p$ $<0,05)$, hipotesa yang ditegakkan asertaya pengaruh hantaran terjadinya laserasi perineum dengan berat baserta bayi lahir diterima, artinya semakin besar berat baserta bayi semakin besar 
terjadinya laserasi perineum pada kehamilan.

Dari penelitian diatas dapat ditarik asumsi bahwa berat baserta lahir mempengaruhi kejadian laserasi perineum. Berat baserta janin dapat mengakibatkan terjadinya laserasi pada jalan lahir yaitu berat baserta baserta janin lebih dari 3500 gram, karena resiko trauma partus melalui vagina seperti distosia bahu serta kerusakan jaringan lunak pada ibu. Semakin besar bayi yang dilahirkan meningkatkan resiko terjadinya laserasi pada jalan lahir dikarenakan semakin besar berat baserta bayi lahir semakin besar kemungkinan terjadi laserasi pada jalan lahir. Berat baserta lahir besar umumnya mempunyai kecenderungan lebih sering mengalami trauma lahir, tetapi keadaan ini masih dipengaruhi oleh cara kelahiran serta pihak penolong. Jadi ada hubungan berat baserta bayi lahir dengan laserasi jalan lahir pada ibu bersalin normal.

Hasil analisa hubungan umur ibu mempengaruhi kejadian laserasi perineum, umur ibu beresiko yang mengalami laserasi perineum sebesar 27 responden (46,6\%), lebih besar dibanding dengan umur ibu tidak beresiko yang mengalami laserasi perineum sebesar 8 responden (6,7\%). Hasil uji statistik ChiSquare menunjukkan bahwa ada hubungan yang bermakna hantaran umur ibu dengan kejadian laserasi perineum dengan $p$ value 0,001 .

Umur dianggap penting karena ikut menentukan prognosis dalam kehamilan, karena dapat mengakibatkan kesakitan (komplit) baik pada ibu maupun janin. Umur reproduksi optimal bagi seorang ibu adalah hantaran $\geq 20-\geq 35$ tahun. Pada umur kurang dari 20 tahun, organ-organ reproduksi belum berfungsi dengan sempurna sehingga bila terjadi kehamilan serta kehamilan akan lebih mudah mengalami komplit. Selain itu, kekuatan otot- otot perineum serta otot-otot perut belum bekerja secara optimal sehingga sering terjadi kehamilan lama atau macet yang memerlukan tindakan, seperti bedah sesar. Sesertagkan pada usia > 35 tahun fungsi reproduksi seorang wanita sudah mengalami penurunan dibandingkan fungsi reproduksi normal sehingga kemungkinan untuk terjadinya komplit pasca kehamilan terutama perdarahan akan lebih besar (Annisa, 2013).

Penelitian ini sejalan dengan penelitian yang dilakukan oleh Palimpo, 2013 bahwa umur ada hubungan dengan kejadian laseri perineum. Dengan hasil penelitian umur ibu bersalin berisiko $(<20$ atau $>35)$ tahun sebesar 26 orang $(65,4 \%)$ serta umur ibu bersalin tidak beresiko berisiko ( $\geq 20-\leq 35$ tahun) sebesar 17 (34,6\%). Umur ibu tidak berisiko menunjang kesehatan ibu serta perkembangan janin berjalan dengan semestinya serta risiko komplit memungkinkan tidak terjadi seperti terjadinya laserasi perineum. Dari analisis multivariat menunjukkan bahwa $p$ value 0,020 maka dapat disimpulkan ada hubungan hantaran umur ibu dengan laserasi perineum.

Dari penelitian diatas dapat ditarik asumsi bahwa umur mempengaruhi kejadian laserasi perineum. Karena umur ibu beresiko (<20 serta > 35 tahun) rantang terhadap kelainan kehamilan/faktor resiko tinggi kehamilan. Umur tersebut sangat berpengaruh, karena umur 35 tahun merupakan masa dimana sistem reproduksi seorang wanita sudah menurun, sesertagkan umur ibu kurang dari 20 tahun dimana system reproduksinya belum begitu matang untuk bereproduksi, sehingga bila terjadi kehamilan serta kehamilan akan lebih 
mudah mengalami komplit. Selain itu, kekuatan otot-otot perineum serta otot-otot perut belum bekerja secara optimal, sehingga sering terjadi kehamilan lama atau macet yang memerlukan tindakan.

\section{KESIMPULAN}

a. Ada hubungan jarak persalinan dengan kejadian laserasi perineum pada kehamilan normal di RSUD Dr. Ibnu Soetowo Baturaja Kabupaten Ogan Komering Ulu. Hal tersebut dibuktikan pada nilai uji statistik dengan nilai $p$ value 0,002 .

b. Ada hubungan berat badan lahir dengan kejadian laserasi perineum pada kehamilan normal di RSUD Dr. Ibnu Soetowo Baturaja Kabupaten Ogan Komering Ulu. Hal tersebut dibuktikan pada nilai uji statistik dengan nilai $p$ value 0,001 .

c. Ada hubungan umur ibu dengan kejadian laserasi perineum pada kehamilan normal di RSUD Dr. Ibnu Soetowo Baturaja Kabupaten Ogan Komering Ulu. Hal tersebut dibuktikan pada nilai uji statistik dengan nilai $p$ value 0,001 .

\section{DAFTAR PUSTAKA}

Annisa.S.A, 2013. Faktor-Faktor Risiko Ruptur Perinium Di Rsud Dr. Adjidarmo Lebak Pada Bulan Oktober-Desember 2013. Universitas Islam Negeri Syarif Hidayatullah. Jakarta

Data RSUD Ibnu Soetowo Baturaja. 2017. Data Ibu Bersalin serta Ruptur Perineum. Baturaja

Dinkes Palembang. 2015. Data lbu Bersalin serta Ruptur Perineum. Sumatera Selatan. Palembang

Fajrin serta Fitriani. 2015. Hubungan hantaran Berat Baserta Bayi Baru
Lahir pada Kehamilan Fisiologis dengan Kejadian Laserasi Perineum. Jurnal Kebisertaan. Volume 7 / No. 2 / Desember 2015

Hastono. 2014. Metodelogi Penelitian Kesehetan. EGC. Jakarta

Hutomo, (2014), Faktor Resiko Laserasi Pada Jalan Lahir di RS Betesdha Yohayakarta. FK UGM Diakses tanggal 22 Maret 2017. http://insanimj.blogspot. com,

Nugroho. 2014. Patologi Kebisertaan. Medical Book. Jakarta

Palimbo R, 2013. Hubungan Umur serta Paritas Dengan Kejadian Laserasie Perineum Di VK Bersalin RSUD. Dr. Ansari Banjarmasin Tahun 2013. Banjarmasin. Tesis

Prawiroharjo. 2012. Ilmu Kebisertaan. Bina Pustaka. Jakarta

Prawita aa. Hubungan antara paritas dengan kejadian robekan jalan lahir di rsud langsa kota langsa provinsi aceh. 2015;

Purna. R. 2014. Ilmu Kebisertaan Patologi serta Fisiologi Kehamilan. Yogyakarta: Yayasan Essentia Medica

Rahayu, 2016. Faktor yang Berhubungan dengan Kejadian Laserasi Perineum di Puskesmas Mergangsan Kota Yogyakarta. Jurnal Medika Respati. Vol XI Nomor 2 April 2016. ISSN. 1907-3887

Rahmawati I. 2011, Hubungan berat badan lahir dengan derajat ruptur perineum pada persalinan normal di rsia kumala siwi pecangaan jepara. $\mathrm{J}$ kesehatan dan budaya.

Reniwati. 2014. Asuhan Kbisertaan dalam Kehamilan, Prsalinan, Nifas serta Gangguan Reproduksi. Salemba Medika. Jakarta 
Ristiati. Nor 'aini. Wahyunita. 2016. Hubungan Berat Baserta Bayi Lahir Dengan Derajat Laserasi Jalan Lahir Pada Ibu Primipara Di Rs Muhamad Husain. Jurnal Kesehatan serta Budaya. Vol 5 No. 1. ISSN 19071396

Rosdiana.2014. Faktor-Faktor yang mempengaruhi terjadinya rupture perineum pada ibu bersalin normal di Puskesmas Pelayanan Obstetri Neonatal Emergency Dasar (PONED) Darul Imarah. Aceh Besar (Skripsi) Banda Aceh. STles U'Budiyah Banda Aceh

Rosmawar. 2015. Faktor-Faktor Yang Mempengaruhi Terjadinya Laserasi Pada Kehamilan Normal Di Puskesmas Tanah Jambo Aye Panton Labu. Jurnal IImiah STIKes U'Budiyah. Vol.2, No.1, Maret 2016

Sabri. Kusharisupeni. Dartiwen. 2016. Pengaruh Pemijatan Perineum Pada Primigravida Terhadap Kejadian Laserasi Perineum Saat Kehamilan Di Biserta Praktik Mandiri (BPM) Wilayah Kerja Puskesmas Margadadi Kabupaten Indramayu. Jurnal Kesehatan. Vol. 08, No. 02, Agustus 2016

Susanti. 2014. Faktor-Faktor yang Mempengaruhi Kejadian Ruptur Perineum Spontan di BPM Biserta "N" Kota Bandung. Bandung: STIKES Bhakti Kencana Bandung

Wahyuni. 2015. Asuhan Kebisertaan Kgawatdaruratan Maternal serta Neonatal. Sinar Harapan. Jakarta

Yadizah, I, 2013. Faktor-faktor yang mempengaruhi Terjadinya Laserasi Perineum Pada Proses Kehamilan Primipara Studi Di RB Budi Asih Semarang: Tesis. Universitas Muhammadiyah Semarang 